\title{
Corporate Governance and Dividend Policy in Jordan
}

\author{
Asmaa Al-Amarneh ${ }^{1} \&$ Hadeel Yaseen ${ }^{1}$ \\ ${ }^{1}$ Financial and Banking Sciences Department, Private Applied Science University, Amman, Jordan \\ Correspondence: Asmaa Al-Amarneh, Financial and Banking Sciences Department, Private Applied Science \\ University, Amman, Jordan. Tel: 962-795-513-798. E-mail: a_alarneh@asu.edu.jo
}

Received: December12, 2013

Accepted: February10, $2014 \quad$ Online Published: March 25, 2014

doi:10.5539/ijef.v6n4p210

URL: http://dx.doi.org/10.5539/ijef.v6n4p210

\begin{abstract}
This study investigates the relationship between corporate governance and dividend policy in Jordan using a sample of 47 industrial company listed in Amman Stock Exchange (ASE) during the period 2005-2011. The results show that large firms with high investment opportunity set (growth) and high return on equity make large dividend payment, but firms with high financial leverage degree make lesser dividend payment. The random regression wasused to test the relationship between the corporate governance factors (corporate holdings, financial institution holdings, insiders holding and foreign holding) and dividend yield. The corporate holdings and financial institution holdings have a nonlinear relationship with dividend yields, as holdings increase the dividend yields increase up to a certain level of holdings supporting the free cash flow theory, as the insiders and foreign holdings increase the dividend yields decrease supporting the signaling theory.
\end{abstract}

Keywords: corporate governance, dividend yield, insider holdings, institution holdings, corporate holdings, foreign holdings, Jordan

\section{Introduction}

Dividend policy has always been one of the most controversial financial issues for all entity. The question regularly arises that why firms pay dividend. It is a question of consideration and several researches have been focused on dividend policy. Dividend payout policy has considered the most important policy in the financial corporate policies because it is an influential control vehicle to reduce the conflicting interests of the shareholders and directors as shareholders are interested in receiving dividends, while directors prefer to hold earnings. Shareholders typically are the final owners of entity and have residual right on the resources, profits and losses.

Dividend payment is a mechanism to shift the wealth from entity to its owners; as a result, the shareholders are usually trying to have an appropriate policy for dividend that guarantees the maximum shareholders wealth. Large shareholders enjoy more power and motive for the maximum share and enforcing management as they invest a large amount of all financially and non-financially. If one of shareholders collects the required information about the management performance and the mentioned shareholder stops the management using the fortune, the advantages of management control for all the shareholders will be achieved. Large shareholders have more benefit compared to the small shareholders because they have more shares and therefore more benefit in corporation. In addition, controlling shareholders can attain information due to their close to directors that give them an opportunity to have more benefit comparing with other shareholders. According to Jensen (1986) and Rozeff (1982) if dividends are not paid to shareholders, directors will start using these resources for their private benefits. Dividend policy helps the firms to know that how they can control the agency costs by handling the Dividend policy. Jensen (1986) argued that by paying dividends to the shareholders, the managerial control over the resources would reduce. Stouraitis and Wu (2004) suggested that the dividend could be used to squeeze the overinvestment problems of corporations (Free Cash Flow theory). Dividend payout policy will not only assist in reducing the agency costs but will also act as a signal to give information to the shareholders about the firm's valuation (Signaling theory).

The present paper is aimed to investigate the relationship between corporate governance and dividend policy in Jordan using a sample of 47 industrial company listed in Amman Stock Exchange (ASE) during the period 2005-2011. We are going to explain variations in dividend payout behavior of the Jordanian firms with the help of firm's financial structure, investments opportunities, dividend history, earnings trend and the ownership 
structure.

The rest of the paper is organized as follows: Section 2 presents literature review. Section 3 contains a discussion of the hypotheses. Section 4 discusses the methodology and variables. Section 5 reviews results. Section 6 concludes the paper with recommendation.

\section{Literature Review}

Good and effective corporate governance is a crucial and focal point for the development of strong and competitive corporate sector. One of the most important decisions for corporate is dividend policy; such a decision very important because it emerges from corporate governance mechanism. Lately, many research papers and studies had examined the relationship and the effect of dividend policy on corporate governance. Researchers suggest that firms with high dividend payout policies tend to minimize agency problem and the conflicts between small and large shareholders. Ross in his study in (1973) and then a study by Jensen and Meckling (1976) tested and investigated the associated cost, which referred to as agency costs. In addition, a study by Rozeff (1982) examine the same issue by using data for one thousand US firms for the period from 1974 to 1980 . He had introduced the agency cost and the transaction cost, which make the dividend policy. He concluded that when the firms tend to have higher agency cost due to varied in the structure of ownership, the dividend payment would rise up. Crutchley and Hansen in their paper of dividend payout policy (1989) reached to similar results and they find that this policy along with financial leverage is one of the most powerful mechanisms in management control and financial decisions. Farinha (2003) also shows similar evidence in his study of British firms; he examined dividend policy and insider ownership as controlling factors. He found that agency problem increases when the insider ownership goes beyond a specific level, also this requires more dividend payment to minimize the agency problems. Han et al. (1999) in his empirical study had showed a positive and significant relationship between dividend payout and institutional ownership. In addition, Dyck (2000) highlighted that in countries with weak governance standards, foreign owners are likely to export their higher standards and apply them to firms in the host country. Ajinkya et al. (2005) indicated that effective corporate governance structures constrain corporate managers and/or controlling shareholders from expropriating other investors by monitoring an environment of greater transparency, then foreign investors are more likely to be more dependent on effective corporate governance structure. The rationale for this argument is that foreign investors are usually minority shareholders and face higher risk of being expropriating by corporate managers and/or controlling shareholders. The recent literature acknowledges the role of foreign investors as important media in monitoring shareholder's interest and play a very significant role in improving corporate governance.

Stouraitis and $\mathrm{Wu}$ (2004) used a sample of Japanese firms, they found that the dividend payout policy can be used to manage and control the overinvestment problems of firms, they also found that there is a conflict of interests between directors and shareholders regarding the dividend policy and theses decisions are vary depending on growth opportunities. El-Masry et al. (2008) have found similar evidence in a study, they found a significant relationship between institutional ownership and dividend payout policy; this is because the fact that institutional ownership typically voted for higher payout ratios. Harada and Nguyen (2009) also provide similar evidence that supports theories and studies about ownership concentration is associated with lesser dividend payments which is illustrated as a percentage of operating earnings. Nmazi and kermani (2008) examined the impact of the ownership structure of Iranian firms from 2007 to 2010. They found a negative relationship between the institutional ownership and the value of the firm while there is a positive relationship between ownership structure and firm performance.

In Jordan, Omit (2004) shows that Jordanian firms apply stable dividend policies, also he found that imposing taxes on dividends do not affect dividend decisions, and lagged dividend per share is more effective than current earnings per share when determining the existing dividend per share. In addition, Al-Malkawi (2007) showed that the amount of stocks held by insider and state ownership strongly affects the decision of dividend payment and the amount of dividends paid. In addition, he found that size of the firm, age, and profitability are the focal determinants of corporate dividend policy in Jordan. His results support the hypothesis of agency costs and consistent with previous studies. Al-Najjar (2010) in his study presents that institutional investors consider the following factors when determining their dividend and investment decisions such as, firm's capital structure and leverage, profitability, business risk, asset structure and size, asset liquidity ratios, and growth rates. Al-Amarneh et al. (2011) investigate the institutional investors' preferences; the results show that dividend Yield and stock volatility do not seem to play an important role in institutional choice. By assuming asymmetric adjustment toward the target dividend payout, Zurigat and Gharaibeh (2011) in their study of 35 Jordanian firms investigated the effect of ownership structure oncorporation dividend policy. They found that institutional ownership provides 
incentives forshareholders to use their influence for maximizing the value of firms byreducing the use of funds in investments with low return, and cash flows can be distributed as dividends. They conclude that Jordanian firms donot depend on dividends as a technique to minimize the agency problem betweendirectors and shareholders. Warrad et al. (2012) show evidence that there is a positive and significant relationship between foreign ownership and dividend payout policy.

Not only leverage and dividend the only financial tools examined by literature to discuss the agency problem, or working on alleviating the costs associated and its impact on the firm's value. The presence of large institutional shareholders or insider ownership is considering one of the important issues and expected to line up the interest of both shareholders and directors. Hence, one could expect that the ownership structure would affect the corporate dividend decisions. Most researches focused on studying the relationship between ownership structure and dividend policy for firms located in developed countries where financial markets in these countries are regulated efficiently and firm's ownership is widely diversified. As an attempt to consider other markets which are less regulated, this paper is examined the relationship by using Jordanian firms, however, it is distinguished from the other ones on the basis of proxies of dependent and independent variables. An empirical dividend model has been used to investigate the relationship between dividend policy and ownership structure of Jordanian corporations listed on the Amman Stock Exchange.

\section{Hypotheses Development}

Research Hypotheses: Corporate governance is a mechanism that takes in consideration the shareholders interest and the Stakeholder's interest, then help to mitigate the agency problem. After reviewing the literature, our paper is going to examine whether differences in ownership structure and owners identity across firms can explain their dividend payout differences in Jordan. The paper aim is to answer the following questions: Does shareholders identity matter? If it does, then, whether directors' ownership is more effective than foreign ownership, corporate ownership or institutional ownership in determining the firm's dividend payout policy? Does dividend signal any conflict between the insiders? In addition, the study aims to test empirically the following hypothesis:

H0: there is no statistically significant relationship between dividend yield and corporate governance factors.

\section{Methodology}

\subsection{Sample Selection and Sources of Data}

Our sample consists of industrial firms listed in Amman Stock Exchange (ASE) (73) companies; we exclude firms with incomplete or unavailable information. We end up with a sample of (47) industrial firms (64.4\% of whole population). The firm's common-stock shares have been listed without interruption on the ASE between 2005 and 2011, and all financial data and ownership related data are fully available. The data used in this study were drawn from ASE company guides and publications, while Institutional ownership data are from Jordanian securities Depository Center (SDC).

\subsection{Model and Variables}

\subsubsection{Variables}

In this paper, the corporate governance components have been analyzed. The relationship between these attributes and dividend yield has been examined.

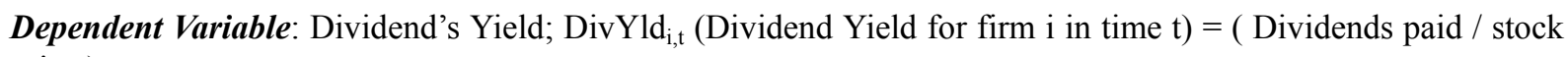
price ).

Independent Variables: Corporate Governance.

After reviewing the literature (Malkawi, 2007; Zurigat \& Gharaibeh, 2011; Warrad et al., 2012), the governance factors in this paper include the ownerships of insiders, corporate, financial institution and foreign. The ownership of insiders (INS) component was measured by the ratio of insider stockholdings for those who own 5\% or more of the total outstanding shares. In the same way, the corporate ownership was measured by the ratio of corporate stockholdings (CS). The financial institution ownership (FIS) was measured by the ratio of financial institution (Funds) stockholdings and foreign ownership (FORS) was measured by the ratio of foreign stockholdings.

\section{Control Variables:}

Referring to the literature review, we control for the following firm characteristics:

- Firm size: a proxy for ability to access capital markets SIZE $_{i, t}$ (Firm size of firm $i$ in time $t$ ) $=$ Natural 
logarithm of total assets of firm i.

- Growth (Investment opportunities) Tobin's $\mathrm{Q}_{\mathrm{i}, \mathrm{t}}$ (Market value of assets-to-book value of assets ratio for firm i in time $t)=($ Book value of debt + Market value of equity $) /$ Book value of assets.

- Return on Equity $\left(\mathrm{ROE}_{\mathrm{i}, \mathrm{t}}\right)$ performance of firm (i) in year ( $\mathrm{t}$ ) is measured by ROE = Net income after tax / total common equity.

- Financial Leverage Degree $\left(\operatorname{LEV}_{i, t}\right)$ : is the ratio of total liabilities to total assets for company (i) at year $(t)$.

\subsubsection{Model}

The hypothesis to be tested is that dividend yield of the firm is affected by the corporate governance factors under the control of some firm characteristics. We also include the square of corporate governance factors to examine the presence of ownership effect after a certain threshold. In addition, we note that dividend payments are not only affected by the past dividends, but also affected by investment opportunities, earnings for common equity, financial leverage degree and firm size. We control for unobserved firm-effects $\left(\alpha_{i}\right)$ and $\left(\varepsilon_{i t}\right)$ denotes the error term. In particular, we test the following models:

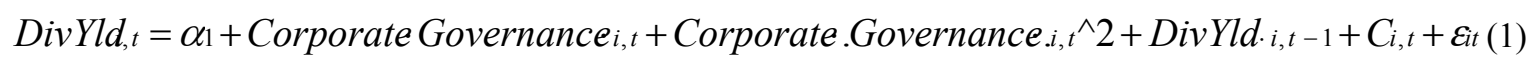

Where $\mathrm{C}_{\mathrm{i}, \mathrm{t}}$ contains control variables (Size, tobins' $\mathrm{Q}$, financial leverage, $\mathrm{ROE}$ ).

\section{Data Description and Empirical Results}

We analyze the corporate governance factors for the selected companies during the period 2005-2011, the results shown in table (1) and Figure 1(a, b, c, d). The statistics show that around $40 \%$ of the capital comes from corporate investors; the large owners hold about $53 \%$ of the capital of ASE companies, $7 \%$ comes from funds and financial institutional investors and 19\% from foreign investors.

Table 1. Descriptive statistics for corporate governance proxies

\begin{tabular}{lllll}
\hline & Corporate holdings & & \multicolumn{2}{l}{ Large owners holdings } \\
\hline Year & Mean & Std. Dev. & Mean & Std. Dev. \\
$\mathbf{2 0 0 5}$ & 0.374135 & 0.243173 & 0.524666 & 0.222732 \\
$\mathbf{2 0 0 6}$ & 0.386124 & 0.230847 & 0.529187 & 0.212833 \\
$\mathbf{2 0 0 7}$ & 0.403295 & 0.240131 & 0.543019 & 0.226274 \\
$\mathbf{2 0 0 8}$ & 0.402792 & 0.248531 & 0.536106 & 0.232849 \\
$\mathbf{2 0 0 9}$ & 0.422366 & 0.244878 & 0.519617 & 0.244234 \\
$\mathbf{2 0 1 0}$ & 0.418710 & 0.247453 & 0.519617 & 0.244234 \\
$\mathbf{2 0 1 1}$ & 0.408203 & 0.247593 & 0.519617 & 0.244234 \\
All & $\mathbf{0 . 4 0 2 2 3 2}$ & $\mathbf{0 . 2 4 1 5 8 5}$ & $\mathbf{0 . 5 2 7 4 0 4}$ & $\mathbf{0 . 2 3 0 7 9 2}$ \\
\hline & Financial Institutions' holdings & Foreign Holdings & \\
\hline Year & Mean & Std. Dev. & Mean & Std. Dev. \\
$\mathbf{2 0 0 5}$ & 0.101152 & 0.098932 & 0.178368 & 0.241550 \\
$\mathbf{2 0 0 6}$ & 0.091007 & 0.095782 & 0.202714 & 0.241652 \\
$\mathbf{2 0 0 7}$ & 0.083665 & 0.095886 & 0.205008 & 0.246372 \\
$\mathbf{2 0 0 8}$ & 0.074576 & 0.101259 & 0.209751 & 0.238930 \\
$\mathbf{2 0 0 9}$ & 0.062111 & 0.092585 & 0.199654 & 0.231512 \\
$\mathbf{2 0 1 0}$ & 0.051556 & 0.076450 & 0.181323 & 0.230784 \\
$\mathbf{2 0 1 1}$ & 0.049823 & 0.076961 & 0.178958 & 0.230659 \\
All & $\mathbf{0 . 0 7 3 2 3 8}$ & $\mathbf{0 . 0 9 2 5 1 6}$ & $\mathbf{0 . 1 9 3 6 8 2}$ & $\mathbf{0 . 2 3 5 5 7 9}$ \\
\hline
\end{tabular}




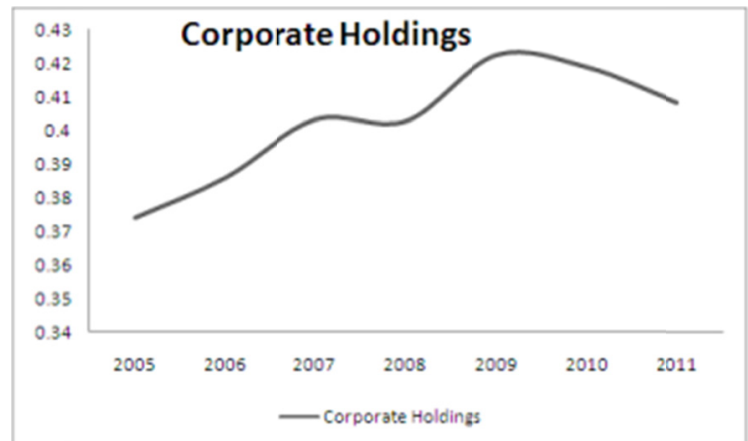

Figure 1a. Corporate holdings

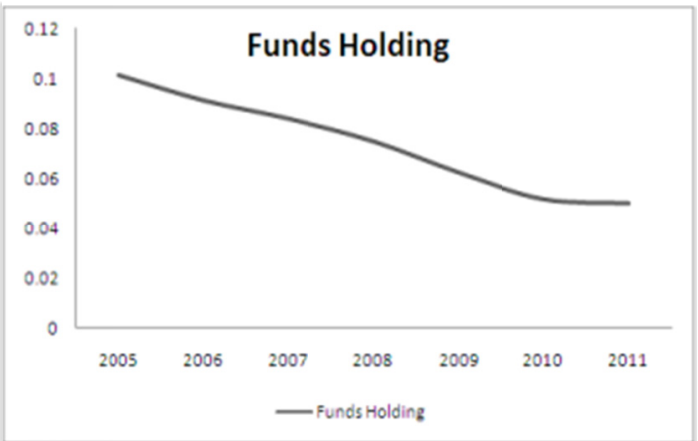

Figure 1b. Fund holdings

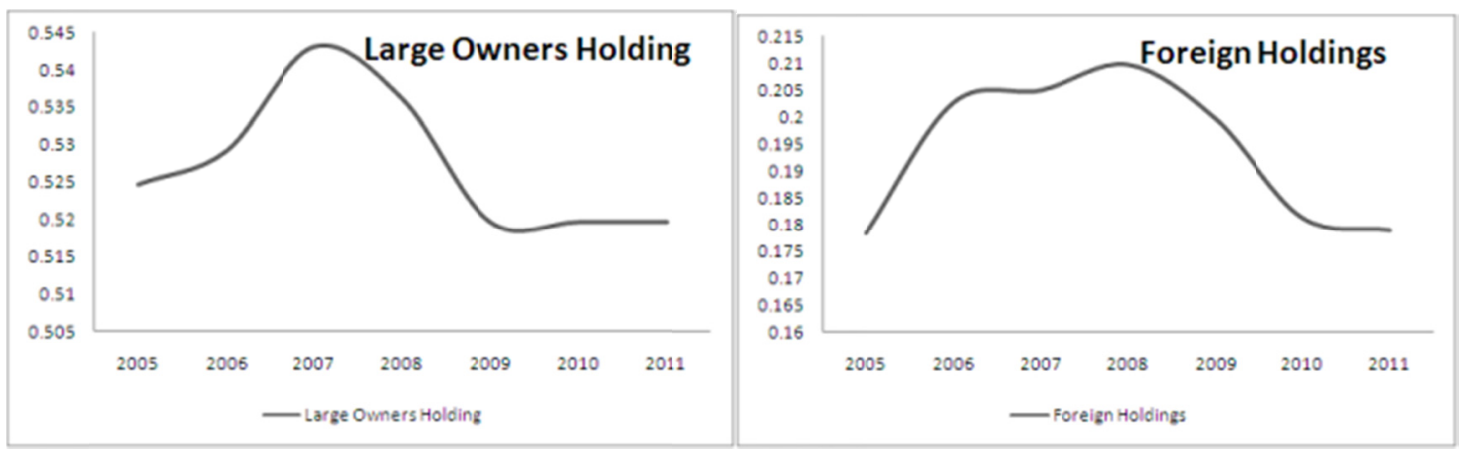

Figure 1c. Large owners holdings

Figure 1d. Foreign holdings

Figure 1. Corporate governance proxies

The statistics in Table 2 show that the mean of dividend yield was $2.3 \%$, with a maximum value of $2.85 \%$ in (2007). The average size of the selected firms was near 15 million Jordanian dinars. The average value for ROE was -0.35 , with annual values decreased from $5.98 \%$ (2005) to -9.03 (2011). The average value for Tobins' $Q$ ratio was 1.6 , it decreased from 1.78 (2005) to 1.37 (2011). The financial leverage degree variable has an average value of $31.22 \%$ which increase in value from $26.4 \%$ (2005) to $35.5 \%$ (2011).

Table 2. Descriptive Statistics for Corporate performance Variables

\begin{tabular}{lllllllllll}
\hline Var & Div.Yld & \multicolumn{2}{c}{ Size } & \multicolumn{3}{c}{ ROE } & \multicolumn{3}{c}{ Tobin's Q } & \multicolumn{3}{c}{ Leverage } \\
Year & Mean & Std. Dev. & Mean & Std. Dev. & Mean & Std. Dev. & Mean & Std. Dev. & Mean & Std. Dev. \\
\hline $\mathbf{2 0 0 5}$ & 0.022570 & 0.039620 & 16.41601 & 1.284036 & 5.976957 & 12.54334 & 1.775323 & 1.198967 & 0.263808 & 0.167127 \\
$\mathbf{2 0 0 6}$ & 0.021808 & 0.027043 & 16.42912 & 1.296547 & 2.570000 & 13.60271 & 1.615894 & 1.063187 & 0.272719 & 0.160650 \\
$\mathbf{2 0 0 7}$ & 0.028477 & 0.046872 & 16.50978 & 1.339865 & 4.485106 & 14.65592 & 1.737424 & 1.337940 & 0.299357 & 0.158386 \\
$\mathbf{2 0 0 8}$ & 0.023821 & 0.052187 & 16.58966 & 1.431858 & -5.819783 & 31.65877 & 1.591980 & 1.150248 & 0.334254 & 0.204396 \\
$\mathbf{2 0 0 9}$ & 0.026220 & 0.035505 & 16.62142 & 1.483286 & -0.589121 & 17.27337 & 1.443858 & 0.961154 & 0.331235 & 0.203528 \\
$\mathbf{2 0 1 0}$ & 0.021900 & 0.029495 & 16.55385 & 1.532640 & -0.205892 & 17.20390 & 1.473142 & 0.967973 & 0.330082 & 0.200200 \\
$\mathbf{2 0 1 1}$ & 0.015353 & 0.026077 & 16.4622 & 1.548102 & -9.032355 & 27.45687 & 1.371389 & 1.000575 & 0.354503 & 0.212225 \\
All & 0.022879 & 0.037704 & 16.51172 & 1.409210 & -0.349503 & 20.77695 & 1.572716 & 1.103539 & 0.312280 & 0.188858 \\
\hline
\end{tabular}

In our study, the governance factors we examined are ownership structure of firms, they were relevant to each other as shown in Table 3, to deal with this problem, we test the impact of ownership variables on dividend yield separately. 
Table 3. Pearson correlation coefficient between governance factors presented by ownership structure of firms

\begin{tabular}{lllll}
\hline Variables & Corporate holdings & Funds holdings & Foreign holdings & Large owners holdings \\
\hline Corporate holdings & 1.000 & & & \\
& & & & \\
Funds holdings & -0.140826 & 1.0000 & & \\
& $(-2.556432)^{* *}$ & & & \\
Foreign holdings & 0.373924 & -0.027044 & 1.0000 & 1.0000 \\
& $7.245867^{*}$ & $-0.486213^{* *}$ & & \\
Large owners holdings & 0.408066 & -0.117643 & 0.442325 & \\
\hline
\end{tabular}

*Value is significant at $1 \%{ }^{* *}$ Value is significant at $5 \%$.

We test the relationship between dividend yield and firm characteristics (investment opportunities Tobins'Q, ROE, Leverage and Size). The results in Table 4 show a positive significant relationship between the dividend yield and all selected control variable except financial leverage which has a negative relationship with dividend yield.

Table 4. Pearson correlation coefficient between dividend yield and firm characteristics

\begin{tabular}{llllll}
\hline Variables & DIVYLD & LEVERAGE & ROE & Tobins'Q & SIZE \\
\hline DIVYLD & 1.000000 & & & \\
LEVERAGE & -0.105523 & 1.000000 & & & \\
& $-1.904172^{* *}$ & & & \\
ROE & 0.331568 & -0.363140 & 1.000000 & & \\
& $6.306519^{*}$ & $-6.993738^{*}$ & & & \\
Tobins'Q & 0.282399 & -0.123961 & 0.147615 & 1.000000 & \\
& $5.282476^{*}$ & $-2.241700^{* *}$ & $2.678195^{*}$ & & \\
SIZE & 0.207642 & 0.133649 & 0.392559 & -0.023180 & 1.000000 \\
& $3.809022^{*}$ & $2.419960^{* *}$ & $7.659041^{*}$ & -0.416064 & \\
\hline
\end{tabular}

${ }^{*}$ Value is significant at $1 \%{ }^{* *}$ Value is significant at $5 \%$.

Also the relationship between dividend yield and corporate holdings level by classifying the dividend yield figures according to corporate holdings level, the results shown in Table 5 and presented by Figure 2 . The results suggest a nonlinear positive concave function; Agha (2008), Jaysh (2006) found similar results.

Table 5. Corporate holdings intervals matching average dividend yield

\begin{tabular}{cccc}
\hline Corporate Holdings Intervals & $\begin{array}{c}\text { Dividend Yield } \\
\text { Mean }\end{array}$ & $\begin{array}{c}\text { Dividend Yield } \\
\text { Std. Dev. }\end{array}$ & Obs. \\
\hline$[0,0.2)$ & 0.013957 & 0.024353 & 87 \\
{$[0.2,0.4)$} & 0.018997 & 0.025691 & 68 \\
{$[0.4,0.6)$} & 0.034249 & 0.053668 & 103 \\
{$[0.6,0.8)$} & 0.026231 & 0.030524 & 52 \\
{$[0.8,1)$} & 0.006807 & 0.012911 & 19 \\
All & $\mathbf{0 . 0 2 2 8 7 9}$ & $\mathbf{0 . 0 3 7 7 0 4}$ & $\mathbf{3 2 9}$ \\
\hline
\end{tabular}




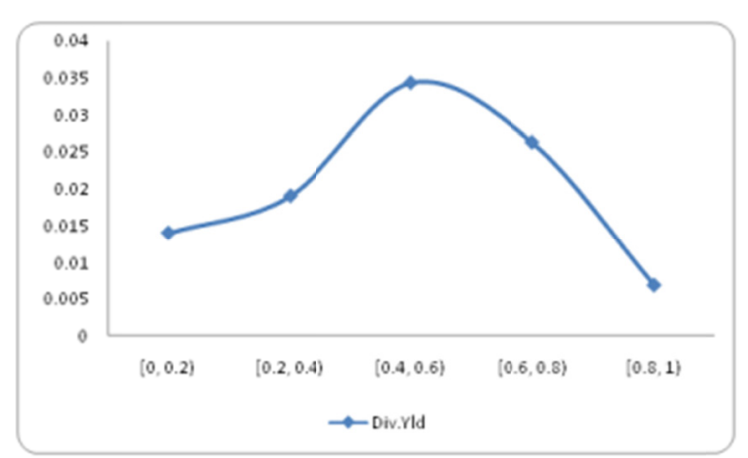

Figure 2. Dividend yield and corporate holdings intervals

When we classify the dividend yield figures according to large owners' holdings level, the results shown in Table 6 and presented by Figure 3 show a negative relationship between the two variables. The classification of dividend yield by financial institution holdings in Table 7and Figure 4 suggest a nonlinear positive concave function. While classification of dividend yield by foreign holdings shown in Table 8 and Figure 5 .

Table 6. Large owners holdings intervals matching average dividend yield

\begin{tabular}{cccc}
\hline Corporate Holdings Intervals & $\begin{array}{c}\text { Dividend Yield } \\
\text { Mean }\end{array}$ & $\begin{array}{c}\text { Dividend Yield } \\
\text { Std. Dev. }\end{array}$ & Obs. \\
\hline$[0,0.2)$ & 0.031294 & 0.028543 & 32 \\
{$[0.2,0.4)$} & 0.021465 & 0.031264 & 60 \\
{$[0.4,0.6)$} & 0.022971 & 0.024926 & 94 \\
{$[0.6,0.8)$} & 0.022987 & 0.052220 & 105 \\
{$[0.8,1)$} & 0.017494 & 0.032254 & 38 \\
All & $\mathbf{0 . 0 2 2 8 7 9}$ & $\mathbf{0 . 0 3 7 7 0 4}$ & $\mathbf{3 2 9}$ \\
\hline
\end{tabular}

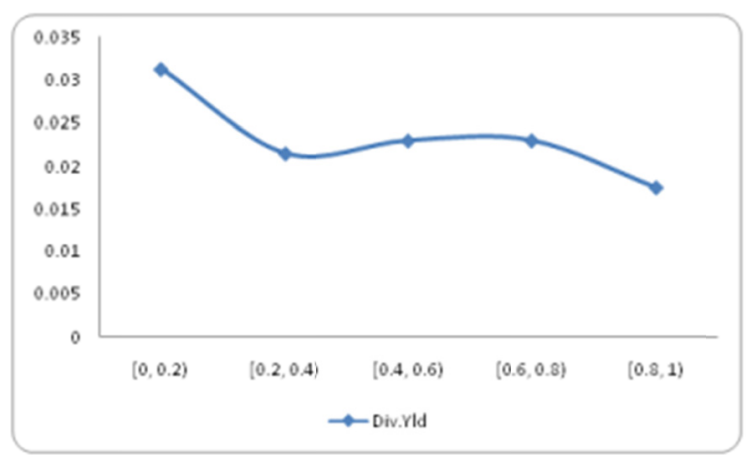

Figure 3. Dividend yield and large owners' holdings intervals

Table 7. Financial institutions holdings intervals matching average dividend yield

\begin{tabular}{cccc}
\hline Corporate Holdings Intervals & $\begin{array}{c}\text { Dividend Yield } \\
\text { Mean }\end{array}$ & $\begin{array}{c}\text { Dividend Yield } \\
\text { Std. Dev. }\end{array}$ & Obs. \\
\hline$[0,0.1)$ & 0.022511 & 0.040731 & 229 \\
{$[0.1,0.2)$} & 0.022627 & 0.026288 & 63 \\
{$[0.2,0.3)$} & 0.040621 & 0.038183 & 21 \\
{$[0.3,0.4)$} & 0.002551 & 0.008067 & 10 \\
{$[0.4,0.5)$} & 0.000000 & 0.000000 & 2 \\
All & $\mathbf{0 . 0 2 2 9 5 1}$ & $\mathbf{0 . 0 3 7 7 8 9}$ & $\mathbf{3 2 5}$ \\
\hline
\end{tabular}




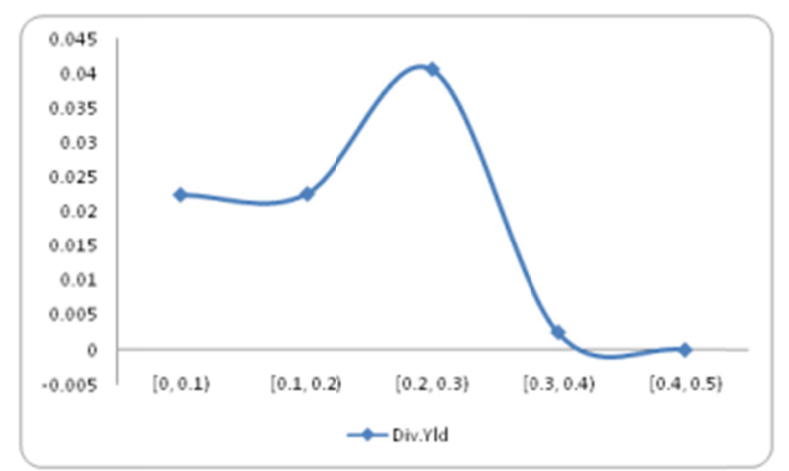

Figure 4. Dividend yield and financial institution holdings intervals

Table 8. Foreign holdings intervals matching average dividend yield

\begin{tabular}{cccc}
\hline Corporate Holdings Intervals & $\begin{array}{c}\text { Dividend Yield } \\
\text { Mean }\end{array}$ & $\begin{array}{c}\text { Dividend Yield } \\
\text { Std. Dev. }\end{array}$ & Obs. \\
\hline$[0,0.2)$ & 0.027144 & 0.041503 & 227 \\
{$[0.2,0.4)$} & 0.008055 & 0.015754 & 37 \\
{$[0.4,0.6)$} & 0.015299 & 0.022676 & 33 \\
{$[0.6,0.8)$} & 0.025567 & 0.039076 & 22 \\
{$[0.8,1)$} & 0.000000 & 0.000000 & 10 \\
All & $\mathbf{0 . 0 2 2 8 7 9}$ & $\mathbf{0 . 0 3 7 7 0 4}$ & $\mathbf{3 2 9}$ \\
\hline
\end{tabular}

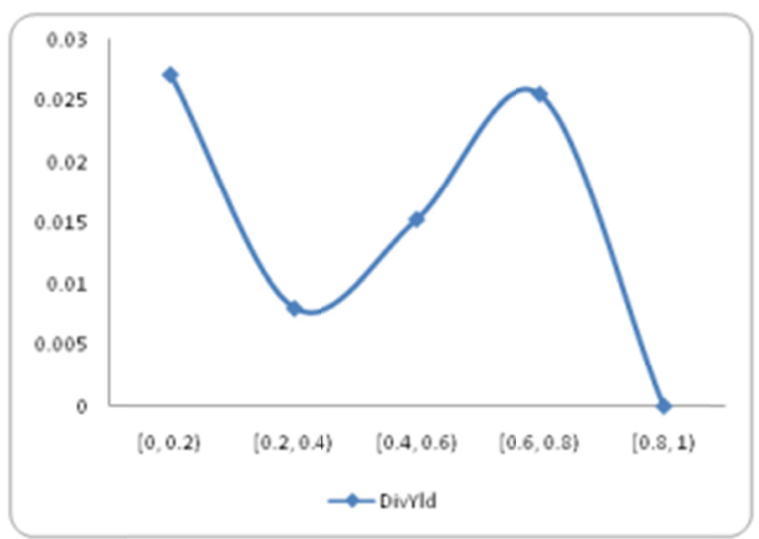

Figure 5. Dividend yield and foreign holdings intervals

According to random effect regression results shown in Table 9, corporate holdings and financial institutions holdings have a nonlinear impact on dividend yield: positive on level and negative in square. As the corporate holdings percentage increase the dividend yield increase until the percentage of corporate holding get over $60 \%$, the dividend yield starts to decrease. In the same way, as the financial institutions holdings increase the dividend yield increase until the percentage of funds holding get over the $30 \%$, the dividend yield starts to decrease.

Table 9. Panel data regression (random effect): Dividend yield and corporate governance factors

\begin{tabular}{lllll}
\hline \multicolumn{1}{c}{ Variables } & \multicolumn{2}{l}{ Corporate Governance Proxies } & & \\
& Corporate Holdings & Large Owners Holdings & Funds \& Institutions Holdings & Foreign Holdings \\
\hline Coefficient for Corporate & $0.041171^{* * *}$ & $-0.021043^{*}$ & $0.090611^{* * *}$ & $-0.029375^{*}$ \\
Governance Proxies. & & & & - \\
Corporate Governance`2 & $-0.047788^{* * *}$ & - & $-0.291204^{* * *}$ & $0.000347^{*}$ \\
ROE & $0.000346^{*}$ & $0.000381^{*}$ & $0.000364^{*}$ & $0.005619^{*}$ \\
Tobins’Q & $0.004895^{*}$ & $0.006461^{*}$ & $0.004843^{*}$ & $0.003375^{* *}$ \\
Size & 0.000708 & 0.001030 & -0.0000118 & \\
\hline
\end{tabular}




\begin{tabular}{|c|c|c|c|c|}
\hline Leverage & -0.002358 & 0.002049 & 0.000224 & 0.001115 \\
\hline DivYld (-1) & $0.392625^{*}$ & $0.393152 *$ & $0.408106^{*}$ & $0.367205^{*}$ \\
\hline Constant C & -0.01041 & -0.002337 & 0.003959 & $-0.044359 * * *$ \\
\hline Adjusted $\mathrm{R}^{2}$ & 0.311775 & 0.321937 & 0.316466 & 0.331667 \\
\hline F-Statistic & 18.92642 & 22.91948 & 19.12254 & 23.91064 \\
\hline Prob. (F-Statistic) & 0.0000 & 0.0000 & 0.0000 & 0.0000 \\
\hline D.W & 2.068445 & 2.082663 & 2.07451 & 2.049395 \\
\hline
\end{tabular}

*Value is significant at $1 \% .{ }^{* *}$ Value is significant at $5 \% .{ }^{* * *}$ Value is significant at $10 \%$.

This result support the free cash flow theory which suggest that firm pays dividend in order to reduce agency costs as payment of dividends reduce the discretionary funds available to managers. The large owners' holding (who owns more than 5\%) and the foreign holdings have a negatively significant relationship with dividend yield in level, suggesting that insiders and foreign stockholders prefer to reinvest earnings in the firm as a signal for future cash flow, under the assumption that outside investors have imperfect information about the firm profitability and the cash dividends are taxed at a higher rate than capital gains.

\section{Conclusion}

This study aims to investigate the relationship between corporate governance and dividend yield on Jordanian industrial firms. The results suggest that large and more profitable companies with high investment opportunities have a higher dividend yield. An ordinary least square regression has been used to test the effect of corporate governance on dividend yield. The overall findings show that corporate holdings and fund's holdings have a positive impact on the dividend yield supporting the free cash flow theory, while Insiders or large shareholders and foreign shareholders have a negative impact on the dividend payment decisions supporting the signaling theory.

\section{References}

Agha, M. (2008). Investment, dividends, firm performance and managerial incentives: Another insight into the role of corporate governance. Retrieved from http://ssrn.com/abstract $=1316878$

Ajinkya, B., Bhojraj, S., \& Sengupta, P. (2005). The association between outside directors, institutional investors and the properties of management forecasts. Journal of Accounting Research, 43, 343-376. http://dx.doi.org/10.1111/j.1475-679x.2005.00174.x

Al-Amarneh, A., Al-Kilani, Q., \& Kaddumi, T. (2011). Institutional preferences: Evidence from the Jordanian Stock Market. International Journal of Economics and Finance, 3(5), 97-103. http://dx.doi.org/10.5539/ijef.v3n5p97

Al-Malkawi, H. N. (2007). Determinants of corporate dividend policy in Jordan: An application of the tobit model. Journal of Economic and Administrative Sciences, 23(2), 44-70. http://dx.doi.org/10.1108/10264116200700007

Al-Najjar, B. (2009). Dividend behavior and smoothing: New evidence from Jordanian panel data. Studies in Economics and Finance, 26(3), 182. http://dx.doi.org/10.1108/10867370910974017

Al-Najjar, B. (2010). Corporate governance and institutional ownership: Evidence from Jordan. Corporate Governance, 10(2), 176-190. http://dx.doi.org/10.1108/14720701011035693

Bebchuk, L., Cohen, A., \& Ferrel, A. (2009). What matters in corporate governance? Review of Financial Studies, 22, 783-827 .http://dx.doi.org/10.1093/rfs/hhn099

Bhagat, S., \& Brain, B. (2008). Corporate governance and firm performance. Journal of Corporate Finance, 14, 257-273. http://dx.doi.org/10.1016/j.jcorpfin.2008.03.006

Carvalhal-da-Silva, A. L., \& Leal, R. P. C.(2004). Corporate governance and value in Brazil (and in Chile). Frontiers in Finance and Economics, 1(1), 1-16.

Crutchley, \& Hansen. (1989). A test of the agency theory of managerial ownership, corporate leverage, and corporate dividend. Financial Management, 18, 36-46. http://dx.doi.org/10.2307/3665795

Dittmar, A., \& Jan, M. S. (2007). Corporate governance and the value of cash holdings. Journal of Financial Economics, 83, 599-634. http://dx.doi.org/10.1016/j.jfineco.2005.12.006

Dyck, A. (2000). Ownership structure, legal protections and corporate governance. In B. Pleskovic \& J. Stiglitz 
(Eds.), Proceedings of the Annual World Bank Conference on Development Economics (pp. 293-332). World Bank.

El-Masry, A. A., Abd-Elsalam, O., \& Elsegini, S. (2008). Board composition, ownership structure and dividend policies in an emerging market: Further evidence from CASE 50. Managerial Finance, 34(12), 953-964. http://dx.doi.org/10.1108/03074350810915879

Farinha, J. (2003). Dividend policy, corporate governance and the managerial entrenchment hypothesis. Journal of Business Finance \& Accounting, 30, 1173-1209. http://dx.doi.org/10.1111/j.0306-686X.2003.05624.x

Han, K. C., Lee, S. H., \& Suk, D. Y. (1999). Institutional shareholders and dividends. J. Financ. Strat., 12(1), 53-62.

Harada, K., \& Nguyen, P. (2009). Ownership concentration, agency conflicts, and dividend policy in Japan. Retrieved from http://ssrn.com/abstract=1458901

Jaysh, K. (2006). Corporate governance and dividend policy in India. Journal of Emerging Market Finance, 5(1), 15-58. http://dx.doi.org/10.1177/097265270500500102

Jensen, M. C., \& William, H. M. (1976). Theory of the firm: Managerial behavior, agency costs and ownership $\begin{array}{lllll}\text { structure. Journal of } & \text { Financial 305-360. }\end{array}$ http://dx.doi.org/10.1016/0304-405X(76)90026-X

Klock, M. S., Sattar, A. M., \& William, F. M. (2005). Does corporate governance matter to bondholders? Journal of Financial and Quantitative Analysis, 40, 693-719. http://dx.doi.org/10.1017/S0022109000001940

Koerniadi, H., \& Tourani, R. A. (2009). Corporate governance, financing pattern and cost of capital: Evidence from New Zealand companies. 22nd Australasian Finance and Banking Conference 2009.

Linter, J. (1956). Distribution of incomes of corporations among dividends, retained earnings and taxes. The American Economic Review, 46, 97-113.

Modigliani, F., \& Miller, M. H. (1958). The cost of capital, corporation finance and the theory of investment. American Economic Review, 48, 261-297.

Omet, G. (2004). Dividend behavior in the Jordanian capital market. International Journal of Business, 9(3), 288-299.

Ross, S. A. (1973). The economic theory of agency: The principal's problem.

Rozeff, S. (1982). Growth, beta and agency costs as determinants of dividend payout ratios. Journal of Financial Research, 5, 249-259.

Stouraitis, A., \& Wu, L. (2004). The impact of ownership structure on the dividend policy of Japanese firms with free cash flow problem. AFFI December meeting.

Suwaidan, M., Abed, S., \& Al-Khoury, A. (2013). Corporate governance and non-jordanian share ownership: The case of Amman stock exchange. International Journal of Business and Management, 8(20), 14-24. http://dx.doi.org/10.5539/ijbm.v8n20p14

Warrad, L., Abed, S., Khriasat, O., \& Al-Sheikh, I. (2012). The effect of ownership structure on dividend payout policy: Evidence from Jordanian context. International Journal of Economics and Finance, 4(2), 187-195. http://dx.doi.org/10.5539/ijef.v4n2p187

Zurigat, Z., \& Gharaibeh, M. (2011). Do Jordanian firms smooth their dividends? Empirical test of symmetric and asymmetric partial adjustment models. International Research Journal of Finance and Economics, 81, 160-172.

\section{Copyrights}

Copyright for this article is retained by the author(s), with first publication rights granted to the journal.

This is an open-access article distributed under the terms and conditions of the Creative Commons Attribution license (http://creativecommons.org/licenses/by/3.0/). 